\title{
PROJECT APPRAISAL AND THE MULTIPLIER: THE CASE OF THE VIPHYA PULP MILL PROJECT IN MALAWI
}

\author{
By B. D. GILES and A. JENNINGS*
}

\section{Introduction}

THE Preparatory Committee for the New International Development Strategy have suggested that development programmes concentrating on one, or a few major projects, are likely to result in more successful implementation and achievement of targets in the Third U.N. Development Decade. [1] This paper is concerned with the problem of measuring the impact on an economy of a major project viz. a wood pulp mill projected to be constructed in Malawi. The location of the mill necessitates also significant investment in roads, hospital facilities, education etc. Indeed a sizeable new town will be created from what is at present largely bush. We briefly describe the major characteristics of the Malawi economy, and outline the nature of a pulpwood project that has been under consideration for some years. We then examine the justification for departing from the orthodox approach to project appraisal in order to incorporate multiplier effects. Finally we present the results of the appraisal.

\section{The Economy and the project}

Since Malawi gained Independence in 1964 the Government has achieved remarkable progress in developing the economy. Prior to independence the economy and social and physical infrastructure had been neglected. In 1964 the population of approximately 4 million had a per capita income of K38 (1 Malawi Kwacha = U.S. \$1.10). By 1978 the per capita income in real terms of the 5.7 million population had risen to $\mathrm{K} 68$. The average annual increase in gross domestic product at constant prices since 1964 has been 6.1 per cent. Table 1 indicates that Malawi is a low income, but open and rapidly developing agricultural economy.

The project is a wood pulp mill to be constructed at Chinteche on Lake Malawi at the edge of the Viphya plateau. The climate and soil of the Viphya plateau are ideally suited for the growing of pine trees. A plantation programme was implemented as early as 1949, and U.K. aid finance has been of assistance in expanding the plantation area to more than 43,000 hectares. The favourable soil and climate make it possible for the pine trees to reach the required maturity at the rotation age of 16 years. Extraction of

\footnotetext{
* Senior Lecturer in Economics, University of Bristol until 1978. He has worked as a government economist in Lesotho, Swaziland, Malawi and Zambia, and visiting Senior Lecturer, University of Zimbabwe, Salisbury. Lecturer in Economics, University of Leicester. He has also worked as a government economist in Botswana and Malawi and as a consultant for the Overseas Development Administration, U.K., and the United Nations.
} 
TABLE 1

The Malawi economy

\begin{tabular}{|c|c|c|c|c|c|c|c|c|}
\hline \multirow{3}{*}{\multicolumn{2}{|c|}{$\begin{array}{l}\text { Population } \\
\text { G.D.P. (at current market prices) }\end{array}$}} & & $\cdot$ & . & & . & \multicolumn{2}{|c|}{5.7 million } \\
\hline & & 1978 & . & .. & . & . . & $\$ 985.8$ & $"$ \\
\hline & & 1964 & . & . . & . & . & $\$ 168.7$ & $"$ \\
\hline \multirow{3}{*}{\multicolumn{2}{|c|}{$\begin{array}{l}\text { G.D.P. per capita (at current } \\
\text { market prices) }\end{array}$}} & & & & & & & \\
\hline & & 1978 & . & . & . & . & $\$ 173.0$ & $"$ \\
\hline & & 1964 & $\cdots$ & . & . & . & $\$ 44.1$ & $"$ \\
\hline \multicolumn{2}{|c|}{ Growth rate G.D.P. } & \multicolumn{5}{|c|}{$1964-78$ at 1964 prices } & \multicolumn{2}{|c|}{$6.1 \%$ per annum } \\
\hline \multicolumn{2}{|c|}{ Exports 1978 (f.o.b.) } & & $\ldots$ & . & $\ldots$ & $\ldots$ & \multicolumn{2}{|c|}{$\$ 173.0$ million } \\
\hline \multirow{2}{*}{\multicolumn{2}{|c|}{$\begin{array}{l}\text { Imports } 1978 \text { (c.i.f.) } \\
\text { Current Account deficit }\end{array}$}} & & . & . & 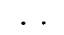 & . & $\$ 244.0$ & $"$ \\
\hline \multirow{2}{*}{\multicolumn{7}{|c|}{$\begin{array}{l}\text { Current Account deficit } \\
\text { Official External Reserves end June } 1978 \text {. . }\end{array}$}} & \multicolumn{2}{|l|}{$\$ 116.0$} \\
\hline & & & & & & & \multicolumn{2}{|l|}{$\$ 80.3$} \\
\hline \multicolumn{7}{|c|}{ Total Agricultural production per cent of G.D.P. } & \multicolumn{2}{|l|}{$43 \%$} \\
\hline \multicolumn{7}{|c|}{ Smallholder production per cent of G.D.P. } & \multicolumn{2}{|l|}{$38 \%$} \\
\hline \multicolumn{4}{|c|}{ Manufacturing production per cent of G.D.P. } & $\cdots$ & $\ldots$ & $\cdots$ & \multicolumn{2}{|l|}{$12 \%$} \\
\hline \multicolumn{3}{|c|}{ Fixed investment per cent of G.D.P. } & . & . & . & . & \multicolumn{2}{|l|}{$30 \%$} \\
\hline Savings ratio & $976 \quad \ldots$ & & . & . & . & $\cdots$ & $16 \%$ & \\
\hline \multicolumn{9}{|c|}{ Principal exports 1978} \\
\hline Tobacco. . & . . & . & . & $\ldots$ & $\ldots$ & $\ldots$ & \multicolumn{2}{|c|}{$\$ 97$ million } \\
\hline Tea & . & . . & . . & . & . & . & $\$ 32$ & $"$ \\
\hline Sugar & . & . & . & . & $\ldots$ & $\ldots$ & $\$ 12$ & $"$ \\
\hline Groundnuts & . & . & . & . & . & . & $\$ 6$ & $"$ \\
\hline Cotton . & . & . & . & $\cdots$ & $\ldots$ & . & $\$ 1$ & $"$ \\
\hline Rice & $\cdots \quad \ldots$ & $\cdots$ & . & $\cdots$ & $\cdots$ & . & $\$ 3$ & $"$ \\
\hline
\end{tabular}

Source: Monthly Statistical Bulletin, National Statistical Office Economic Report 1979. Economic Planning Division (O.P.C.).

the timber will be by ox-skidding to the forest secondary road system, and thence by 35 ton trucks to the pulp mill site on the lakeshore. The bleached long fibre sulphate kraft pulp will be transported by barge and train to a coastal port and by ship to its final export market destination. For the purpose of this exercise to estimate the value of pulp sales, a c.i.f. Mediterranean port price of $\$ 478$ a ton is assumed. The primary benefit of the project is the injection into the economy of a stream of foreign exchange earnings. The location of the mill necessitates also significant investment in roads, hospital facilities, education etc. Indeed a sizeable new town will be created from what is at present largely bush. The capital cost of the industrial part of the project at early 1978 cost levels is taken to be $\$ 242$ million, and the required social infrastructure $\$ 104$ million. The project will create direct employment for approximately 8,000 people.

\section{Justification for the use of the multiplier in the appraisal}

Input-Output analysis was considered as one approach to assessing the impact of the project on the economy. Unfortunately no recent input-output account is available, and if one were constructed little confidence could be 
placed on coefficients derived from a single year. Moreover there is no national income forecasting model, and, even if there were, one would have serious doubts about the parameters.

The multiplier concept was conceived and developed primarily in the context of macro-economic problems, [2]. In conventional project appraisal methodology, [3], [4], while consideration is given to regional income multipliers, and class-income multipliers, planners are advised to include the multiplier effect applicable to short-run aggregate income benefits for the entire economy only under certain conditions. The manuals issued by bilateral and multilateral aid agencies as a guide to project planners, [5], IBRD [6] are also careful to warn against the misplaced use of the multiplier. The use of the multiplier in this particular instance therefore requires justification.

Firstly it is usually argued that with given ratios of leakages from the expenditure flow the national income multiplier is uniform for all autonomous changes in expenditure functions. Thus for an extra $\$ 1$ million invested anywhere in the economy the multiplier effects are the same and one can therefore ignore them in choosing between alternative projects. This assumes that there are alternative projects in which the resources could be used with equivalent effect.

However, in this case, there are no comparable alternatives in sight. The injection of expenditure which motivates the multiplier in this project is an increase in net foreign exchange earnings. By the later 1980s, this is expected to have risen to $\$ 11$ million. With the completion of the major burden of debt service in 1995, thereafter net foreign exchange earnings rise to $\$ 44.8$ million, for all practical purposes, in perpetuity. One theoretical alternative would be a sustained increase of about 15 per cent in agricultural exports (allowing for the import content of exports) over and above what is already in prospect. However, Malawi already has a substantial and vigorous agricultural development programme. The Lilongwe Land Development Programme, which is sometimes quoted as a model by the IBRD is one of four similar projects in the country and the National Rural Development Programme has recently been launched to plan investment in agriculture up to the end of the century. Even if funds were available, it is most unlikely that the rate of agricultural development could be significantly raised above that already planned for the next decade or so. Another apparent alternative would be a programme of manufacturing development to replace imports or increase exports so as to achieve a net improvement in the balance of payments equal to the project's contribution, over and above what will otherwise emerge. This again can be ruled out as not feasible. Most of Malawi's manufacturing consists of simple processing of agricultural crops and is geared very closely to agricultural production, which, as already noted, is close to its maximum rate of growth. Other kinds of manufacturing would have such a high import content that an enormous increase in output would be required to improve the external account to levels achieved by the Project. It is not Government policy to develop uncompetitive industries of 
any kind behind protective barriers, and an examination of the record of the past decade lends support to the view that the policy has been justified.

Very recently, following the fuel crisis and the large rise in fertilizer prices, an investigation of the possibility of developing deposits of coal and pyrites has been started. The results are unlikely to be available for some time, but mineral development is not at present regarded as a realistic alternative.

It can therefore be concluded that if Malawi does not get the benefits of the multiplier effects from Viphya Project, it cannot get them from anywhere else. There is no feasible alternative project or set of projects in sight that will have equivalent effects on income, employment, consumption, savings and the balance of payments.

The second reason sometimes advanced for ignoring multiplier effects is that the rise in income generating expenditure may be brought to a halt prematurely because of bottlenecks in domestic supply, resulting in inflationary pressures and/or balance of payments problems.

The limitation is probably not very important in the case of the Viphya Project. It will be about a decade before the multiplier process really begins to bite and in that time, there should be a substantial expansion of productive capacity. With over 43 per cent of the population below the age of 15 in 1970 (N.S.O. Population Change Survey) and inexorably moving up into the working age groups, labour is not likely to be a bottleneck. Indeed, anything that increases employment opportunities in the 1980s may be regarded as a benefit in itself. Formal education, technical training and apprenticeship programmes will increase the supply of skills, and if these need topping up with a little expatriate expertise the project will itself generate the required foreign exchange. The agricultural development programme should ensure the availability of basic foods. It is also a virtue of the project that it seems likely that, because the project, including the plantations, will employ a large number of workers at relatively low wages, the initial consumption expenditure will be mainly on "poor man's" goods-basic food, locally produced household furniture, equipment and clothing, local house building materials and so on-which are themselves labour intensive, generating further rounds of expenditure on similar goods with a low import content. For these reasons, the bottleneck problem arising because of lack of complementary resources is not expected to be serious. Thus with no alternative use for the funds in sight and the prospect of an adequate supply of co-operating domestic resources, the use of the multiplier to quantify the total impact of the Viphya project is justified.

The multiplier is calculated as the reciprocal of the sum of the marginal leakages from the flow of expenditures. The leakages usually identified are savings imports and taxes. Two problems have arisen in estimating the size of the multiplier in Malawi. First, there is the question of whether to derive the marginal ratios from changes in total G.D.P. or from changes in monetary G.D.P., and secondly, the treatment of taxes.

The National Accounts distinguish between monetary and non-monetary 
production, the latter accounting for about 31 per cent of G.D.P. at factor cost in 1978 compared with about 47 per cent in 1964. It would, however, be erroneous to think of two separate sectors. Non-monetary income is, in fact, production for own use, and a very high proportion of Malawians-probably the great majority-have some income of this kind, mainly food production for family consumption. There are few, if any, families who are wholly in the subsistence/barter sector, although there are some whose income is entirely monetary. Families who have a subsistence income invariably have a cash income as well-from wages and salaries, trade or sale of crops. Expenditure may reasonably be regarded as a function of total income not monetary income alone. In a good crop year, the marketable surplus will be large and monetary income for smallholders higher, with consequential effects on their purchases of goods for consumption and investment and on their cash savings. In a bad crop year, a family finding itself with a food deficit, will have to use part of its monetary earnings or savings to buy food and cut down in other directions. The first impact of the project will be on monetary income, but how that income is disposed of will be related, among other things, to what is happening to subsistence income. It has therefore seemed proper to derive the marginal ratios for savings, imports and taxes from changes in total G.D.P., not from monetary G.D.P. only.

With regard to taxes, Government expenditure on services such as education and health is so constrained by revenue that any increase in receipts from taxation would quickly find its way into the expenditure stream. In some models for developed countries, where the level of Government expenditure may be regarded as policy determined and year to year variations in tax revenues mainly affect the borrowing requirement, taxes may be treated as a leakage. In Malawi, the pressure for development means that Government expenditure is maintained very close to the ceiling that is consistent with balance of payments equilibrium for a very open economy. Estimates of the marginal tax ratio indicate that it is fairly small (approximately 0.09 ). Since the taxes are immediately pumped into the economy in the form of government expenditure they are not considered as a leakage.

For the multiplier analysis the relevant ratios can be grounded in recent experience. The multiplier, $k$, is calculated from:

$$
k=\frac{1}{s+m}
$$

where $s=$ the incremental ratio of savings to total G.D.P. over the period 1970 to 1978 and $m=$ the incremental ratio of imports to total G.D.P. over the period 1970 to 1978 .

Although the National Accounts and Balance of Payments figures are of good quality, errors in the year to year variations could lead to serious 
TABLE 2

Calculation of marginal ratios

\begin{tabular}{|c|c|c|c|c|c|c|}
\hline & & & & \multicolumn{3}{|c|}{$K$ million } \\
\hline & & & & 1970 & & 1978 \\
\hline \multicolumn{7}{|c|}{ A. Calculation of Marginal Savings Ratio } \\
\hline 1. Total G.D.P. at current mar & et prices & . & . & 272.0 & & 896.0 \\
\hline 2. Change in Total G.D.P. & . & $\cdots$ & . & \multicolumn{3}{|c|}{624.0} \\
\hline 3. Total Gross Savings & . . & . & $\ldots$ & 18.1 & & 143.6 \\
\hline 4. Change in Total Savings & . & $\ldots$ & $\ldots$ & \multicolumn{3}{|c|}{125.5} \\
\hline 5. Marginal Savings Ratio (s) & $\cdots$ & . & . & \multicolumn{3}{|c|}{0.20} \\
\hline \multirow{2}{*}{\multicolumn{4}{|c|}{$\begin{array}{l}\text { B. Calculation of Marginal Import Ratio } \\
\text { 1. Import of Consumption and Intermediate goods }\end{array}$}} & & & \\
\hline & & & & 55.0 & & 144.8 \\
\hline 2. Change in Imports & . & $\cdots$ & . & \multicolumn{3}{|c|}{89.8} \\
\hline 3. Marginal Import Ratio $(m)$ & . & & . & \multicolumn{3}{|c|}{0.14} \\
\hline
\end{tabular}

Sources: National Accounts Reports 1964/71; N.S.O. Table B; Economic Reports 1970 to 1979; Balance of Payments Reports.

errors in the estimated ratio. To reduce the probable error, changes in savings, imports and central government revenue between 1970 and 1978 have been expressed as fractions of the change in G.D.P. over the same period, all at current prices. It is thought that this should reduce the uncertainties about the annual figures and give results that can be accepted with some confidence (See Table 2). Gross savings, estimated annually in each Economic Report show a good deal of variation from year to year. Being the relatively small difference between the large aggregates (G.D.P. and Consumption), small errors in the original estimates produce quite large errors in estimated savings in any year. The marginal savings ratio is estimated to be 0.20 .

The relevant imports are those induced by the expenditure of domestic income. To a very large extent imports of capital goods are dependent on

TABLE 3

Estimation of the multiplier

\begin{tabular}{|c|c|c|c|c|c|c|}
\hline & & & & $-15 \%$ & $\begin{array}{c}\text { Central } \\
\text { Estimate }\end{array}$ & $+15 \%$ \\
\hline Savings Ratio & . . & . & . . & 0.17 & 0.20 & 0.23 \\
\hline Import Ratio & . . & . & . & 0.12 & 0.14 & 0.16 \\
\hline Total & . & . & . & 0.29 & 0.34 & 0.39 \\
\hline$\left(k=\frac{1}{s+m}\right)$. & . & . & . & 3.45 & 2.94 & 2.56 \\
\hline
\end{tabular}

Notes: Where $k=$ the Multiplier; $s=$ the marginal savings ratio; $m=$ the marginal import ratio. 
grants and loans from abroad rather than on the level of income. This is certainly true of the public sector and largely true of the private sector. In order to concentrate on the imports that are related to income, the import ratio is based on the change in imports for consumption and for intermediate use between 1970 and 1978 . The marginal import ratio is estimated to be 0.14 .

The results have been calculated for the estimated marginal ratios, and for sets of ratios 15 per cent either side of them, in order to examine the sensitivity of the impact of the project if the Multiplier varies.

\section{The results of the appraisal}

The benefit stream of the project is the net direct foreign exchange earnings from the exported pulp. This stream of injections into the flow of income and expenditure in Malawi will induce further increases in income, consumption, savings, imports, and tax revenues via the operation of the multiplier.

The results are set out for what may be thought of as an average year in the late 1980 s, when the process will have raised national income to a new equilibrium level, and for 1996 which is the first year that all the interest and amortization for the mill is paid off, and the burden of infrastructure loan redemption falls significantly, (Table 4). The multiplier effects of the initial construction period are omitted because setting up the mill is a once for all injection not a regular stream, and its import content is high, making its contribution to the domestic expenditure stream rather small. The imports at this stage would be financed by loans from abroad whose service and redemption is allowed for in the calculations.

The impact of the Project on Malawi Gross Domestic Product (G.D.P.) is calculated by the Multiplier $(k)$, times the net direct foreign exchange receipts in that year $(F)$.

The impact of the Project on Savings and Imports, are calculated from $r k(F)$ where:

$r=$ the relevant marginal propensity

$k=$ the multiplier

$F=$ the net direct foreign exchange receipts.

Consumption of Malawi domestically produced goods and services is derived as the residual. The net improvement in the foreign trade balance is equal to the net direct foreign exchange receipts in that year, less the induced imports.

The stability of all categories of expenditure except consumption when all the ratios are changed uniformly one way, or the other, was not unexpected. A bigger $s$, or $m$, reduces the multiplier $k$, so that the changes are bigger proportions of a smaller income.

The sensitivity of the projects impact on the National Economy to 
TABLE 4

The project's estimated net direct foreign exchange earnings (U.S. \$ million at 1st January, 1978 prices)

\begin{tabular}{lll}
\hline & 1988 & 1996 \\
\hline
\end{tabular}

A. Receipts

$\begin{array}{lllllll}\text { (a) Value of Pulp Sales c.i.f. Mediterranean Port } & \ldots & \ldots & \ldots & 86.1 & 86.1\end{array}$

Less

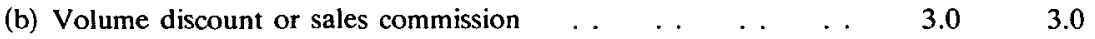

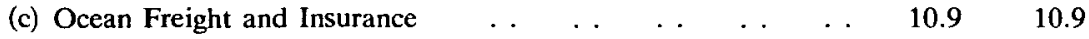
(d) Nacala harbour dues . $\quad \begin{array}{lllllllll} & \ldots & \ldots & \ldots & \ldots & \ldots & \ldots & 0.7 & 0.7\end{array}$

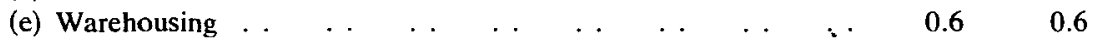

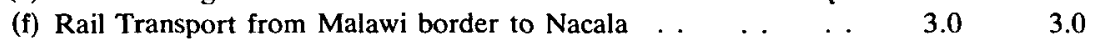
$\begin{array}{lllllllllll}\text { (g) Insurance } & \ldots & \ldots & \ldots & \ldots & \ldots & \ldots & \ldots & \ldots & 0.1 & 0.1\end{array}$

Equals
(h) Value of Pulp at border
$67.8 \quad 67.8$

B. Payments
Capital charges
(a) Interest . .
(b) Amortization
(c) Replacements .
$\begin{array}{lllllllll}\ldots & \ldots & \ldots & \ldots & \ldots & \ldots & \ldots & \ldots & 2.0\end{array}$
$2.0-$
15.0
0.5

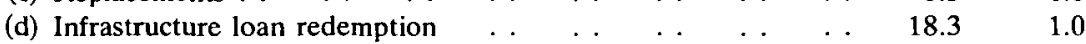
$-$

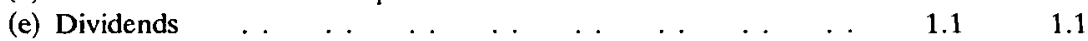
$\begin{array}{lllllllll}\text { (f) External loan service charge } & \ldots & \ldots & \ldots & \ldots & \ldots & 0.6 & 0.6\end{array}$ Operating costs
(g) Lake fleet
$\begin{array}{llllll}\ldots & \ldots & \ldots & \ldots & \ldots & 0.7\end{array}$
$\begin{array}{ll}0.7 & 0.7\end{array}$

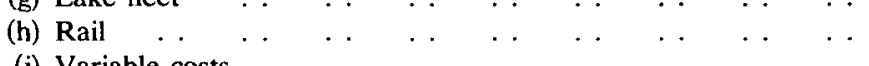
$1.8 \quad 1.8$
$\begin{array}{lllllllll}\text { (i) Variable costs } \ldots & \ldots & \ldots & \ldots & \ldots & \ldots & \ldots & \ldots & 8.7\end{array}$

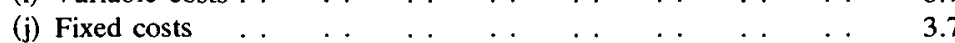

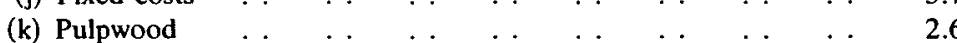
8.78
$\begin{array}{llllllllllll}\text { (l) Fuelwood } & \ldots & \ldots & \ldots & \ldots & \ldots & \ldots & \ldots & \ldots & 0.3 & 0.3\end{array}$

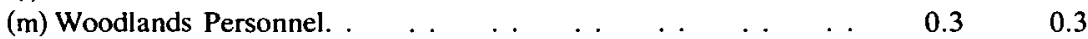
$1.2 \quad 1.2$

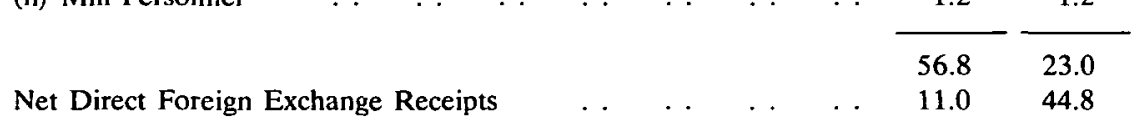

TABLE 5

Impact of the project on G.D.P. (Million U.S. \$)

\begin{tabular}{lccccccc}
\hline & \multicolumn{3}{c}{$\begin{array}{c}\text { Central } \\
\text { Estimate of } \\
\end{array}$} & \multicolumn{3}{c}{$k$} & \multicolumn{2}{c}{$k+15 \%$} & \multicolumn{2}{c}{$k-15 \%$} \\
& 1988 & 1996 & 1988 & 1996 & 1988 & 1996 \\
\hline Increase in G.D.P. & 32.3 & 131.7 & 28.1 & 114.7 & 38.0 & 153.5 \\
\hline
\end{tabular}


TABLE 6

Impact of the project on savings, imports, consumption and the foreign trade balance (Million U.S.\$)

\begin{tabular}{lcccccc}
\hline & \multicolumn{2}{c}{$\begin{array}{c}\text { Central } \\
\text { Estimate of } k\end{array}$} & \multicolumn{2}{c}{$k+15 \%$} & \multicolumn{2}{c}{$k-15 \%$} \\
& \multicolumn{2}{c}{$(2.94)^{\prime}$} & \multicolumn{2}{c}{$(2.56)^{\prime}$} & \multicolumn{2}{c}{$(3.45)^{\prime}$} \\
& 1988 & 1996 & 1988 & 1996 & 1988 & 1996 \\
\hline $\begin{array}{l}\text { Increase in Savings } \\
\begin{array}{l}\text { Increase in Imports } \\
\text { Increase in Consumption } \\
\quad \text { from Malawi }\end{array}\end{array}$ & 6.5 & 26.3 & 6.5 & 26.3 & 6.5 & 26.1 \\
$\quad \begin{array}{l}\text { Production } \\
\begin{array}{l}\text { Net Minimum } \\
\text { improvement in }\end{array}\end{array}$ & 21.3 & 18.4 & 4.5 & 18.4 & 4.5 & 18.4 \\
$\quad$ Foreign Balance & 67.0 & 17.1 & 70.0 & 27.0 & 109.0 \\
\hline
\end{tabular}

Note: See Table 3 for estimate of the multiplier $k$.

changes of plus and minus 15 per cent of the central estimate of net foreign exchange earnings of the mill is shown in Table 7.

The analysis indicates that even with variations of 15 per cent in the major parameters, namely the multiplier, and net foreign exchange earnings of the mill, the Project still makes a major contribution to the development of the National Economy.

We may illustrate the impact of the project on the National Economy against the development of the economy up to 1988 and 1996 . Extrapolating on the basis of trend growth since 1964, the Project will increase Gross domestic Product in 1988 by 1.9 per cent and in 1996 by 4.8 per cent, assuming the central estimate of $k$. Implementation of the Project will increase Savings by 2.3 per cent in 1988 , and 5.9 per cent in 1996 , and

TABLE 7

Sensitivity analysis of $a$ change in net foreign exchange eamings by + and -15 per cent (Million U.S.\$)

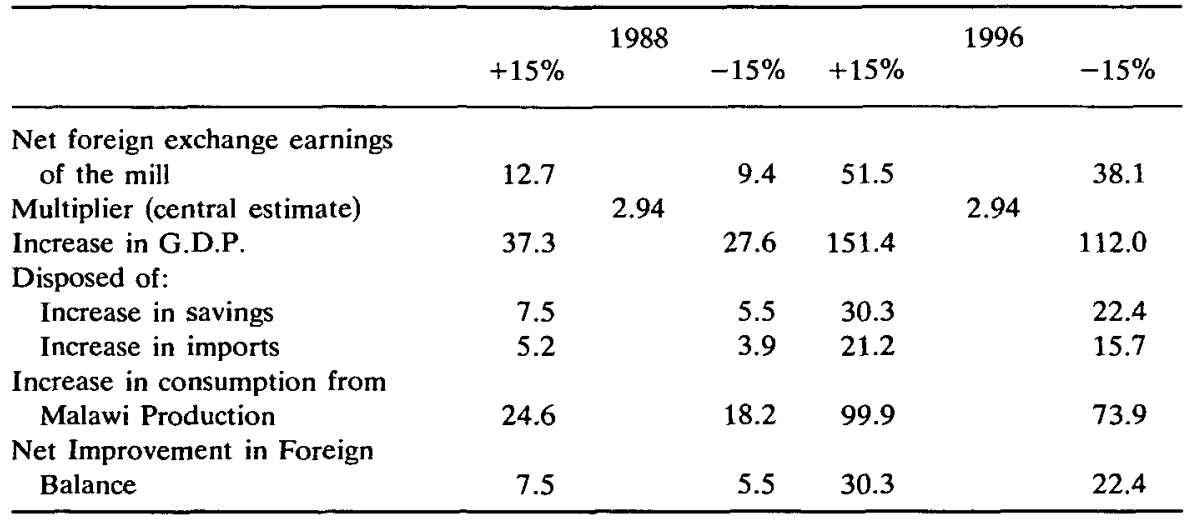


Imports by 0.7 per cent in 1988 , and by 2.0 per cent in 1996 . These figures also illustrate the fact that with the general growth of the economy, the project should easily be absorbed in the development process.

\section{Employment and the project}

The project will have a major impact on employment possibilities in Malawi. The primary creation of employment is estimated to be 8,200 . It has not been possible to estimate a separate employment multiplier, and it is assumed to be roughly the same as the income multiplier. Applying the multiplier gives a central estimate for total employment creation of 24,000 new jobs. These are employment opportunities at all levels. There will be some concentration of new jobs around the project area, but a substantial number of new jobs will be created in a variety of occupations throughout the country. With 43.5 per cent of the population below the age of 15 in 1970 (NSO Population Change Survey, page 13) moving into the working age groups, the project has an obvious contribution to make to solving the possible problems of employment of new entrants to the labour force.

\section{Internal rate of return and the project}

In present conditions in Malawi, the economic rate of return is little different from the financial rate of return. The cash flow includes no subsidies and the direct taxes on inputs are very small indeed, being of the order of $\$ 0.2$ million per annum. Adjusting the price of inputs from market prices to factor costs increases the rate of return by a fraction of one per cent.

It is not at present Malawi Government policy to use shadow prices in economic appraisal. The general indications are that, on the whole, market prices net of taxes are a reasonable approximation to economic opportunity costs. The two areas in which shadow pricing is considered from time to time are of course labour and foreign exchange.

(a) Wages. Government has a very firm policy of restraining wages. The minimum daily wage in Blantyre, the main commercial and industrial centre, is 40 tambala $(=\$ 0.44)$ per day and, outside the main urban areas, the minimum is 25 tambala $(=\$ 0.27)$ per day. As a result, there is no significant unemployment problem and in fact there appear to be some areas of labour shortage; there is also of course a scarcity of some skills. It appears that the labour market is roughly in equilibrium at current wage levels, and there are therefore no grounds for a shadow wage.

How long this view of things will be appropriate is a matter for conjecture. With an estimated 43 per cent of the population under the age of 15 in 1970 the rate of growth of the working population will be rapid; should it outstrip the rate at which employment opportunities can be created the use of a low shadow wage rate may be appropriate in economic appraisal.

(b) Foreign exchange. Malawi's terms of trade have been deteriorating in 
recent years, and world inflation may make it difficult to maintain reserves at a safe working level (usually 2 to 3 months import cover). Thus it may be that, in the course of the next decade, a premium on foreign exchange may be justified, thereby enhancing the social value of the project.

As a substantial user of labour and a net earner of foreign exchange, shadow pricing would give an economic rate of return substantially higher than the financial rate of return. There is therefore reason to conclude that the project will look much more attractive in the 1980s than it does now.

The internal rate of return is estimated for the project. The benefits are taken as the incremental stream of Gross Domestic Product, based on net direct foreign exchange earnings per annum times the central estimate of the multiplier. The costs of the project include all external debt service, and all equity dividends, and that part of the soft finance which has an opportunity cost for Malawi, in terms of benefits foregone from investment in alternative development projects. The resulting Internal Rate of Return for the project is $12 \%$.

The project is based on a renewable resource namely timber. Its net benefits may therefore be projected indefinitely into the future, in contrast to a mineral deposit which is depleted with use. Although the application of any discount rate will show a very small present value for distant benefits, there are grounds for scepticism about the validity of applying DCF techniques to compare projects based on renewable resources with projects based on exhaustible resources. For two projects having the same present value at the same discount rate, and similar in other relevant respects too, one dependent on renewable assets is clearly preferable to one based on nonrenewable assets. The Viphya project merits whatever premium is appropriate for this advantage.

\section{Unquantifiable aspects of the project}

National. The direct and indirect effects of the project will create a new pole of economic growth in the Northern Region in line with Government policy, and more effectively than could probably be achieved by a gradualist approach.

\section{Linkages}

(i) backward: limestone, minor tools and parts for forest and mill and possible coal from nearby deposits.

(ii) forward: the most obvious one is the possibility of a paper mill to manufacture long fibred paper products for export markets, both in central and southern African countries, as their economies develop, and overseas.

A project of this size with the overseas contacts that are inherent in its operations can be expected to attract other industrial ventures to the country, although it must be noted that without effective local participation foreign investment on this scale also has its dangers as well as advantages. 
Environment. Treatment of effluent before discharge into the Lake has been included in the project and the dispersion of emissions into the air has been studied with satisfactory results.

Regional Issues. As a landlocked country Malawi is especially vulnerable to disruption to its transit routes to the sea. It is assumed in this analysis that the situation in neighbouring countries is such that imports can be received, and the product can be exported, without undue difficulty. Considerable emphasis is being given at an international level particularly by UNCTAD, to devising a framework of agreements whereby the transit rights of landlocked countries may be secured.

\section{The multiplier and non-marginal projects}

It is possible that in the smaller less developed countries a Malawi/Viphya type of situation may frequently be found. Small countries are unlikely to have a wide variety of resources, and the alternative to one big additional project based on these resources may be no additional project at all. So long as the project would not run into bottlenecks in the supply of internal resources or of foreign exchange it would be proper to allow for multiplier effects in appraising it.

It should be noted that the inclusion of multiplier effects will not necessarily make a project look more attractive. Bottlenecks may be revealed that either show the project to be impracticable at the macro-economic level, or reveal the need for complementary action which may be costly to improve its chances of success. This suggests that there is always a case for trying to estimate multiplier effects, at least in the appraisal of larger projects.

So far we have considered the matter solely from the point of view of the host country. From the standpoint of an international institution which adopted the economic theorists' aim of maximising world income the case for including multiplier effects would be weaker. Assuming its funds to be strictly limited, the alternative to financing a project in Malawi may be financing one in Peru-or even in the United States. Unless there are known differences in the size of the multiplier in different countries it could then be omitted in comparing projects. But the international community is not indifferent to world income distribution, and several financial institutions have been specificially created to assist the poorer countries. For these institutions the possible alternatives will not range over the whole world, and there will more often be a case for taking the multiplier into account in judging whether assistance should be given to a project in a particular country. It might be worth exploring the possibility of attaching poverty weights (based perhaps on the reciprocal of per capita GDP) to the multiplier in different countries when they are competing for limited funds.

University of Leicester and

United Nations Conference on Trade and Development, Geneva. 


\section{REFERENCES}

1. Report of the Preparatory Committee for the New International Development Strategy, Official records of the U.N. Economic and Social Council, 1979, Supplement No.7, (E/1979/37).

2. KAHN, R. F. Home Investment and Unemployment, Economic Joumal, 1931.

3. Little, I. M. D., and Mirrlees, J. A. Project Appraisal and Planning for Developing Countries, Heinemann, 1974.

4. U.N.I.D.O, Guidelines fo Project Evaluation, United Nations, New York, 1972.

5. Ministry of Overseas Development, A Guide to the Economic Appraisal of Projects in Developing Countries, H.M.S.O., 1977.

6. International Bank for Reconstruction and Development, L. Squire, and H. Q. Van Der Tak, Economic Analysis of Projects, Johns Hopkins, 1975. 